\title{
ANALISIS PEMAHAMAN MAHASISWA AKUNTANSI TERHADAP KONSEP DASAR AKUNTANSI
}

\author{
Reny Wardiningsih \\ Universitas Teknologi Mataram \\ reny.wardi@yahoo.com
}

\begin{abstract}
This study aims to examine the understanding of Accounting Students related to the basic concept of accounting, namely the understanding of assets, liabilities and capital based on the background of secondary schools (Vocational Accounting, Social Sciences and Natural Sciences Senior High School). Sampling through a purposive sampling technique that is a number of 90 accounting students from Mataram University and Mataram University of Technology who filled out the research questionnaire. This study uses SPSS 18 data processing, with a different test, testing the hypothesis shows the result that H3 is accepted, which is a significance level of 0.044 where the value is less than 0.05; and concluded that there are significant differences regarding the understanding of capital between students from SMK Accounting, SMA IPS and IPA SMA, while H1 and H2 are not accepted, the significance level is 0.724 and 0.874 , respectively, where the value is greater than 0.05 . This happens due to several factors including: lack of practice, lack of practice, short study portions, etc., causing a lack of understanding of students towards assets and liabilities which are important indicators of other financial statements.
\end{abstract}

Keywords: Students, Understanding Assets, Liabilities and Capital

\begin{abstract}
Abstrak : Penelitian ini bertujuan menguji pemahaman Mahasiswa Akuntansi terkait dengan konsep dasar akuntansi yaitu pemahaman aktiva, kewajiban dan modal berdasarkan latar belakang sekolah menengah (SMK Akuntansi, SMA IPS dan SMA IPA). Pengambilan sampel melalui metode teknik purposive sampling yaitu sejumlah 90 mahasiswa Akuntansi Universitas Mataram dan Universitas Teknologi Mataram yang mengisi kuesioner penelitian. Penelitian ini menggunakan pengolahan data SPSS 18, dengan uji beda, pengujian hipotesis menunjukkan hasil yaitu $\mathrm{H} 3$ diterima yaitu tingkat signifikansi sebesar 0,044 di mana nilai tersebut lebih kecil dari 0,05; dan disimpulkan bahwa terdapat perbedaan signifikan mengenai pemahaman modal antara mahasiswa yang berasal dari SMK Akuntansi, SMA IPS maupun SMA IPA, sedangkan $\mathrm{H} 1$ dan $\mathrm{H} 2$ tidak diterima yaitu tingkat signifikansi masing-masing adalah 0,724 dan 0,874 dimana nilai tersebut lebih besar dari 0,05 . Hal tersebut terjadi karena beberapa faktor antara lain: kurangnya latihan, minimnya praktik, porsi belajar singkat dll, sehingga menyebabkan kurangnya pemahaman mahasiswa terhadap aktiva maupun kewajiban yang merupakan indikator penting laporan keuangan lainnya.
\end{abstract}

Kata Kunci: Mahasiswa, Pemahaman Aktiva, Kewajiban dan Modal

Manazhim : Jurnal Manajemen dan Ilmu Pendidikan

Volume 2, Nomor 2, Agustus 2020; 143-156

https://ejournal.stitpn.ac.id/index.php/manazhim 


\section{PENDAHULUAN}

Salah satu bidang ilmu yang paling menjadi favorit dan sangat diminati oleh masyarakat yang mengenyam pendidikan tinggi adalah pendidikan ekonomi akuntansi. Kondisi ini terjadi karena bidang ilmu ekonomi menjadi motor penggerak aktifitas perusahaan dan negara. Salah satu bidang ilmu ekonomi yang memiliki peranan penting bagi pertumbuhan ekonomi dan sangat dibutuhkan perusahaan adalah ilmu akuntansi. Oleh sebab itu sebagian besar perguruan tinggi di NTB memiliki jurusan ekonomi akuntansi. ${ }^{1}$

Pendidikan akuntansi bertujuan menghasilkan lulusan yang beretika dan bermoral tinggi. Berbagai upaya dilakukan untuk memperkenalkan nilai-nilai profesi sebagai seorang akuntan yang profesional kepada mahasiswa. Dalam upaya pengembangan pendidikan akuntansi yang berlandaskan profesionalisme ini dibutuhkan adanya umpan balik (feedback) mengenai kondisi yang ada sekarang, yaitu apakah pendidikan akuntansi di Indonesia telah cukup membentuk nilai-nilai positif mahasiswa akuntansi. Jurusan akuntansi menurut sebagian mahasiswa dinyatakan sebagai bidang ilmu yang sulit, kondisi tersebut terjadi karena mahasiswa yang masuk kejurusan akuntansi berasal dari sekolah dan jurusan yang berbeda. Mahasiswa yang memilih jurusan akuntansi tidak semuanya berasal dari ilmu sosial ekonomi, sebagian besar dari mereka mengenyam konsentrasi pendidikan IPA sewaktu di SMA atau pun mahasiswa yang berasal dari sekolah kejuruan seperti SMK. ${ }^{2}$

Di dalam dunia perguruan tinggi, pembelajaran tentang ilmu akuntansi mendapatkan porsi yang sangat khusus, dalam hal ini mahasiswa diberikan mata kuliah dibidang akuntansi dasar dengan porsi waktu yang relatif panjang yaitu 3 sks dalam satu minggu ditambah dengan jam asistensi. Pada saat melakukan pembelajaran bidang ilmu akuntansi dasar, seorang mahasiswa akan diberikan materi tentang siklus akuntansi, mulai dari instrumen keuangan yang paling dasar seperti kas,

1 Ali, Adrizul, Dandes Rifa dan Daniati Putri. 2014. Analisis Tingkat Pemahaman Mahasiswa Terhadap Dasar-Dasar Akuntansi Berdasarkan Asal Sekolab dan Jurusan. Jurusan Akuntansi, Fakultas Ekonomi, Universitas Bung Hatta.

2 Sar'I., M., Irsadsyah, M., Djamil Nasrullah .2010. Analisis Tingkat Pemahaman Mahasiswa Akuntansi terhadap Konsep Dasar Akuntansi (Studi Empiris pada Mahasiswa Akuntansi S1 Uin Suska Riau yang Berasal dari Latar Belakang Sekolah Menengah yang Berbeda). Makalah: Universitas Islam Negeri Sultan Syarif Kasim Riau. 
piutang dan persediaan. Salah satu kunci untuk menguasai ilmu akuntansi adalah mengerti akan konsep dasar akuntansi itu. Apabila dasar akuntansi telah dikuasai dengan baik semua orang pasti akan dengan mudah menjalani dan mempraktekkannya. Salah satu cara seseorang untuk memahami dasar akuntansi tersebut yaitu memilih akuntansi sebagai jurusan pilihan pada pendidikan formal mulai dari jenjang pendidikan menengah sampai ke perguruan tinggi. Meskipun pada kenyataannya pemahaman pendidikan akuntansi yang didapat sewaktu di pendidikan menengah berbeda dengan pendidikan akuntansi yang akan di dapat di bangku perkuliahan. Perbedaan ini terlihat bahwa pembelajaran akuntansi di pendidikan menengah ataupun SMA sederajat berbeda antara satu sama lainnya.

Berdasarkan kepada fenomena dan latar belakang masalah, peneliti tertarik untuk membuat replikasi penelitian yang telah dilakukan oleh $\mathrm{Novious}^{3}$ dan $\mathrm{Ali}^{4}$ yaitu Analisis Pemahaman Mahasiswa Akuntansi terhadap Konsep Dasar Akuntansi (Studi pada Mahasiswa Akuntansi Universitas Mataram dan Universitas Teknologi Mataram yang berasal dari latar belakang sekolah menengah yang berbeda).

Dalam penelitian ini dapat diajukan beberapa pertanyaan yang akan dibahas yaitu apakah terdapat perbedaan pemahaman mahasiswa akuntansi terhadap aktiva, kewajiban dan modal jika dilihat berdasarkan asal sekolah dan jurusan. penelitian ini bertujuan untuk mengetahui perbedaan pemahaman mahasiswa akuntansi terhadap aktiva, kewajiban dan modal yang dilihat berdasarkan asal sekolah dan jurusan.

\section{KAJIAN PUSTAKA}

\section{Pengertian Akuntansi}

Akuntansi adalah seni daripada pencatatan, penggolongan dan peringkasan pada peristiwa-peristiwa dan kejadian-kejadian yang setidak-tidaknya sebagian bersifat keuangan dengan cara yang setepat-tepatnya dan dengan petunjuk atau dinyatakan dalam uang, serta penafsiran terhadap hal-hal yang timbul daripadanya. ${ }^{5}$

\footnotetext{
${ }^{3}$ Novious Andri. 2010. Analisis Pemahaman Mahasiswa Akuntansi Dalam Menghadapi Mata Kuliah Dasar Dasar Akuntansi (Studi Pada Mahasiswa Akuntansi S1 Universitas Islam Negeri Sultan Syarif Kasim Riau). Fokus Ekonomi Volume 5 Nomor 2 Desember 2010.

${ }^{5}$ Munawir, S, 2004. Analisa Laporan Kenangan. Penerbit Liberty, Yogyakarta.
} 
Dari defenisi akuntansi tersebut di ketahui bahwa peringkasan dalam hal ini dimaksudkan adalah pelaporan dari peristiwa-peristiwa keuangan perusahaan yang dapat diartikan sebagai laporan keuangan. Jadi laporan keuangan menurut Myer dalam bukunya Financial Statement Analysis adalah : Dua daftar yang disusun oleh Akuntan pada akhir periode untuk suatu perusahaan. Kedua daftar itu adalah daftar Neraca atau Daftar Pendapatan atau Daftar Rugi Laba. Pada waktu akhir-akhir ini sudah menjadi kebiasaan bagi perseroan-perseroan untuk menambah daftar ketiga yaitu Daftar Surplus atau Daftar Laba yang tidak dibagikan/laba yang ditahan. ${ }^{6}$

Laporan keuangan merupakan salah satu bentuk yang telah ditetapkan sebagai pertanggung jawaban, maka perusahaan harus konsisten melaksanakannya agar laporan keuangan tersebut dapat dipedomani dengan baik serta untuk menghindari anggapan-anggapan yang kurang baik terhadap perusahaan. Dengan demikian laporan keuangan tersebut dapat dinilai serta diperbandingkan dengan periodeperiode sebelumnya.

\section{Konsep Dasar Pemahaman Akuntansi}

Konsep dasar pemahaman akuntansi terdiri dari tiga bagian utama yaitu aktiva, hutang dan modal.

\section{a. Aktiva}

Dalam pengertian aktiva tidak terbatas pada kekayaan perusahaan yang berwujud saja, tetapi juga termasuk pengeluaran-pengeluaran yang belum dialokasikan (deffered changes) atau biaya yang masih harus dialokasikan pada penghasilan yang akan datang, serta aktiva yang tidak berwujud lainnya (intangible asset) misalnya goodwill, hak paten, hak menerbitkan dan sebagainya.

\section{a1. Aktiva Lancar}

Adalah semua harta perusahaan yang dapat direalisir menjadi uang kas atau dipakai atau dijual dalam satu kali perputaran normal perusahaan (biasanya dalam jangka waktu satu tahun). Elemen-elemen yang termasuk dalam aktiva lancar antara lain:

${ }^{6}$ Ibid... 
- Kas,

- Persediaan,

- Piutang, baik piutang dagang maupun piutang wesel.

- Piutang lainnya yang belum tertagih sampai pada akhir periode akuntansi.

- Semua investasi sementara.

- Semua beban/biaya yang dilakukan dimuka dan masih merupakan piutang pada akhir periode Akuntansi.

\section{a2. Aktiva Tetap}

Merupakan aktiva perusahaan yang tidak dimaksudkan untuk diperjualbelikan melainkan untuk digunakan dalam kegiatan perusahaan yang umurnya lebih dari satu tahun dan merupakan pengeluaran perusahaan dalam jumlah yang relatif besar.

\section{a3. Aktiva Tetap Tidak Berwujud}

Yaitu aktiva yang tidak mempunyai sifat-sifat fisik tetapi mempunyai kegunaan. Seperti Hak Paten, Copyright, Organization cost atau Biaya pendirian Francise, Good will, dan sebagainya.

\section{A4. Beban / Biaya Yang ditangguhkan}

Biaya yang dibayar dimuka (Prepaid Expenses) dan biaya yang ditangguhkan (Deferred Charge) merupakan biaya-biaya yang telah dikeluarkan akan tetapi mempunyai kegunaan atau menjadi beban tahun-tahun yang akan datang.

\section{A5. Aktiva Lain-Lain}

Merupaka semua aktiva perusahaan yang tidak dapat digolongkan dalam aktiva tersebut diatas, misalnya mesin-mesin yang tidak dapat dipakai lagi.

Hasil penelitian Ramadhani ${ }^{7}$ menunjukkan hasil bahwa tidak terdapat perbedaan secara signifikan terhadap pemahaman tentang aktiva antara mahasiswa yang berasal dari SMK Jurusan Akuntansi, SMA Jurusan IPS dan SMA Jurusan IPA.

\footnotetext{
7 Ramadhani, E. Wulan. 2017. Analisis Tingkat Pemahaman Mahasiswa Akuntansi terbadap Konsep Dasar
} Akuntansi. FEB Universitas Muhamadiyah Surakarta. 
Hasil Penelitian ini didukung oleh Penelitian Sar' ${ }^{8}$ Hasil penelitian menunjukkan bahwa mahasiswa Jurusan Akuntansi S1 UIN Suska Riau yang berasal dari SMK Jurusan Akuntansi, SMA Jurusan IPS dan Madrasah Aliyah Umum mempunyai penilaian yang sama akan konsep dasar akuntansi terutama teori tentang aktiva yang menjelaskan bahwa kekayaan perusahaan yang berwujud dan pengeluaranpengeluaran yang belum dialokasikan (deferred changes) atau biaya yang masih harus dialokasikan pada penghasilan yang akan datang.

Novious ${ }^{9}$ hasil penelitiannya menunjukan bahwa tidak terdapat perbedaan yang signifikan pemahaman terhadap aktiva antara mahasiswa berasal dari SMK jurusan IPS, mahasiswa tamatan SMA jurusan IPS dan mahasiswa yang berasal dari madrasah. Didalam penelitian tersebut menunjukan pemahaman terhadap aktiva pada mahasiswa tamatan SMK jurusan IPS lebih baik dari mahasiswa yang berasal dari SMA dan Madrasah. Berdasarkan teori dan beberapa hasil penelitian terdahulu maka dapat diambil hipotesis 1 yaitu:

\section{Ha1: Terdapat perbedaan secara signifikan terhadap pemahaman tentang aktiva antara mahasiswa berasal dari SMK Jurusan Akuntansi, SMA Jurusan IPS dan SMA jurusan IPA}

\section{b. Hutang}

Hutang adalah semua kewajiban keuangan perusahaan kepada pihak lain yang belum terpenuhi, dimana hutang ini merupakan sumber dana atau modal perusahaan yang berasal dari kreditur. Hutang atau kewajiban perusahaan dapat dibedakan ke dalam hutang lancer (hutang jangka pendek) dan hutang jangka panjang. ${ }^{10}$ Hutang lancar ialah semua kewajiban keuangan yang harus di penuhi dalam satu periode operasi normal dan yang termasuk dalam hutang lancar. Sedangkan macam-macam hutang antara lain :

- Hutang Dagang (Account Payable)

- Wesel Bayar (Note Payable)

\footnotetext{
${ }^{8}$ Ibid...

${ }^{9}$ Ibid...

10 Ibid...
} 
- Hutang yang timbul karena jasa-jasa yang sudah diterima tetapi belum dibayar (Accrued Expenses).

- Hutang atau Kewajiban Bersyarat (Contingent Liabilities)

- Pendapatan Yang Diterima Dimuka ialah semua penerimaan-penerimaan yang telah diterima tahun berjalan tetapi bukan merupakan penghasilan tahun berjalan sampai dengan akhir periode.

- Hutang-hutang Jangka Panjang ialah semua kewajiban yang akan dilunasi dalam jangka waktu lebih dari satu tahun.

- Hutang-hutang Lainnya ialah semua kewajiban yang tidak dapat digolongkan kedalam hutang lancar maupun hutang jangka panjang.

Penelitian Ramadhani ${ }^{11}$ menunjukkan hasil bahwa tidak terdapat perbedaan secara signifikan terhadap pemahaman tentang kewajiban antara mahasiswa yang berasal dari SMK Jurusan Akuntansi, SMA Jurusan IPS dan SMA Jurusan IPA. Penelitian ini didukung oleh Sar' ${ }^{12}$ Hasil penelitian menunjukkan bahwa mahasiswa Jurusan Akuntansi S1 UIN Suska Riau yang berasal dari SMK Jurusan Akuntansi, SMA Jurusan IPS dan Madrasah Aliyah Umum mempunyai penilaian yang sama akan konsep dasar akuntansi terutama teori tentang kewajiban. Berbeda dengan Penelitian Mawardi ${ }^{13}$ menunjukan bahwa terdapat perbedaan pemahaman mahasiswa tentang kewajiban antara mahasiswa yang berasal dari SMK jurusan akuntansi, mahasiswa tamatan SMA jurusan IPS dan mahasiswa tamatan madrasah. Hasil penelitian tersebut menunjukan mahasiswa SMK jurusan Akuntansi memiliki pemahaman yang lebih baik dari mahasiswa lain yang berasal dari SMA jurusan IPS maupun mahasiswa tamatan Madrasah. Berdasarkan teori dan beberapa hasil penelitian terdahulu maka dapat diambil hipotesis 2 yaitu:

Ha2: Terdapat perbedaan secara signifikan terhadap pemahaman tentang kewajiban antara mahasiswa berasal dari SMK Jurusan Akuntansi, SMA Jurusan IPS dan SMA jurusan IPA.

11 Ibid...

12 Ibid...

13 Mawardi Cholid M. 2010. Tingkat Pemahaman Mahasiswa Akuntansi Terhadap Konsep Dasar Akuntansi di Perguruan Tinggi Negeri di Kota Malang. Jurnal Akuntansi Nomor 5 Volume 2. Universitas Brawijaya, Malang. 


\section{c. Modal}

Adalah merupakan hak atau bagian yang dimiliki oleh pemilik Perusahaan yang ditunjukkan dalam pos modal (modal saham), surplus dan laba yang ditahan. Atau kelebihan nilai aktiva yang dimiliki oleh perusahaan terhadap seluruh hutanghutangnya. ${ }^{14}$

Dalam perusahaan yang berbentuk perusahaan terbatas, modal dapat diklasifikasikan antara lain :

- Modal yang disetor (modal saham, tambahan modal disetor / agio saham, hadiah / donasi).

- Laba yang ditahan (Retained Earning).

- Modal Penilaian (Appraisal Capital).

Ramadhani ${ }^{15}$ hasil penelitiannya menunjukan bahwa tidak terdapat perbedaan pemahaman modal antara mahasiswa akuntansi yang berasal tamatan SMK jurusan IPS, mahasiswa yang berasal dari tamatan SMA jurusan IPS dan mahasiswa tamatan madrasah. Penelitian ini didukung oleh Novious ${ }^{16}$ Pemahaman yang lebih baik dan tinggi adalah dimiliki oleh mahasiswa akuntansi tamatan SMK. Proses pembelajaran akuntansi yang dilakukan secara berulang ulang membuat mereka lebih mahir secara teori maupun praktek dari mahasiswa lain.

Pada penelitian Sar' ${ }^{17}$ menunjukkan hasil bahwa terdapat perbedaan secara signifikan terhadap pemahaman tentang modal antara mahasiswa yang berasal dari SMK Jurusan Akuntansi, SMA Jurusan IPS dan Madrasah Aliyah Umum. Hasil penelitian menunjukkan bahwa mahasiswa Jurusan Akuntansi S1 UIN Suska Riau yang berasal dari SMK Jurusan Akuntansi, SMA Jurusan IPS dan Madrasah Aliyah Umum mempunyai penilaian yang berbeda akan konsep dasar akuntansi, terutama teori tentang modal yang dijelaskan bahwa modal merupakan hak atau bagian yang dimiliki oleh pemilik perusahaan atau kelebihan nilai aktiva yang dimiliki oleh

\footnotetext{
14 Ibid...

15 Ibid...

16 Ibid...

17 Ibid...
} 
perusahaan terhadap seluruh kewajibannya. Berdasarkan teori dan beberapa hasil penelitian terdahulu maka dapat diambil hipotesis 3 yaitu:

Ha3: Terdapat perbedaan secara signifikan terhadap pemahaman tentang modal antara mahasiswa berasal dari SMK Jurusan Akuntansi, SMA Jurusan IPS dan SMA jurusan IPA

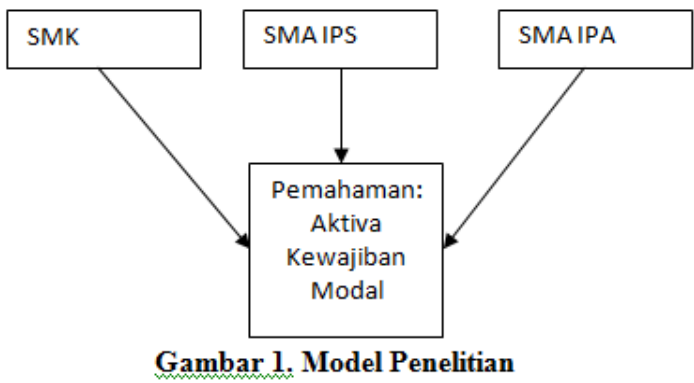

\section{METODE PENELITIAN}

\section{Populasi dan Sampel}

Populasi yang digunakan dalam penelitian ini adalah mahasiswa akuntansi Universitas Mataram dan Universitas Teknologi Mataram. Pengambilan sampel dalam penelitian ini menggunakan purposive sampling yaitu pengambilan sampel berdasarkan kriteria, ${ }^{18}$ yaitu mahasiswa yang berlatang belakang sekolah dari SMK Jurusan Akuntansi, SMA Jurusan IPS dan SMA jurusan IPA. Jumlah sampel yang digunakan dalam penelitian ini sebanyak 90 orang. SMK Jurusan Akuntansi : 30 orang; SMA IPS : 30 orang dan SMA IPA: 30 orang

\section{Jenis, Sumber, dan Teknik Pengumpulan Data.}

Jenis data adalah data primer. Sumber data dalam penelitian ini diperoleh dari penyebaran kuesioner, wawancara langsung dan studi pustaka. Teknik pengumpulan data yang digunakan dalam penelitian ini adalah a five point likert-scale kuesioner. Pengukuran variabel menggunakan instrumen skala likert 1-5 point. Dengan pilihan jawaban STS (Sangat Tidak Setuju) $=1$, TS $($ Tidak Setuju $)=2$, TT $($ Tidak Tahu $)=3$,

18 Indriantoro, Nur, dan Bambang Supomo, 2002. Metodelogi Penelitian Bisnis Untuk Akuntansi Dan Manajemen. Edisi-1,. Yogyakarta, BPFE. 
$\mathrm{S}($ Setuju $)=4$, SS $($ Sangat Setuju $)=5$, dimana responden diberi kebebasan untuk beropini pada kuesioner tersebut.

\section{Metode Analisis Data}

Dalam sebuah penelitian, data yang diperoleh harus diuji terlebih dahulu sebelum memasuki proses analisis. Pengujian data yang dilakukan meliputi pengujian validitas (keabsahan) dan pengujian reliabilitas. ${ }^{19}$

\section{Pengujian Kualitas Data}

Ketetapan penelitian suatu hipotesis sangat tergantung pada kualitas data yang dipakai. Kualitas data penelitian suatu hipotesis sangat tergantung pada kualitas data yang dipakai didalam penelitian tersebut.

\section{Pengujian Hipotesis}

Pengujian hipotesis dalam penelitian ini yaitu menggunakan Uji Data Tiga sampel (independen) yang tidak berhubungan yaitu uji Kruskal Wallis yaitu untuk mengetahui perbedaan pemahaman tentang aktiva, kewajiban dan modal antara mahasiswa berasal dari SMK Jurusan Akuntansi, SMA Jurusan IPS dan Madrasah Aliyah Umum yang dilihat dari nilai signifikansi. ${ }^{20}$

\section{HASIL PENELITIAN DAN PEMBAHASAN}

\section{Statistik Deskriptif Penelitian}

Analisa data dilakukan terhadap 90 sampel responden yang telah memenuhi kriteria untuk dapat diolah lebih lanjut. Hasil pengolahan data statistik deskriptif ditunjukkan pada tabel dibawah ini :

Tabel 1. Statistik Deskriptif Responden
\begin{tabular}{|l|c|c|c|c|c|}
\hline & N & Min & Max & Mean & Std. Dev \\
\hline Aktiva & 90 & 2,00 & 5,00 & 3,98 & 0,485 \\
\hline Kewajiban & 90 & 2,00 & 5,00 & 3,93 & 0,492 \\
\hline Modal & 90 & 3,00 & 5,00 & 3,56 & 0,520 \\
\hline Valid N & 90 & & & & \\
\hline
\end{tabular}

Sumber: Data primer yang diolah

19 Ghozali, Imam (2005), Analisis Multivariat dengan Program SPSS. Badan Penerbit Universitas Diponegoro, Semarang.

20 Santoso, Singgih, 2004. Mengolah Data Statistik Secara Profesional Versi 10. Penerbit Elex Media Komputindo, Jakarta 
Dalam tabel diatas terlihat bahwa variabel aktiva mempunyai nilai minimum sebesar 2,00, nilai maksimum sebesar 5,00, dan nilai rata-rata sebesar 3,98. Jika jawaban rata-rata responden lebih tinggi dari 5,00, maka responden tersebut memiliki pengetahuan yang lebih tinggi tentang aktiva. Variabel kewajiban mempunyai nilai minimum 2,00 dan nilai maksimum 5,00 dan nilai rata-rata yaitu sebesar 3,93. Jika jawaban responden lebih tinggi dari 3,393, maka responden tersebut memiliki pengetahuan yang lebih tinggi tentang kewajiban. Variabel modal mempunyai nilai minimum 3,00 dan nilai maksimum 5,00 dan nilai rata-rata yaitu sebesar 3,56, jika jawaban responden lebih tinggi dari 3,56, maka responden tersebut memiliki pengetahuan yang lebih tinggi tentang modal.

Pengujian hipotesis untuk mengetahui perbedaan pemahaman tentang aktiva, kewajiban dan modal antara mahasiswa berasal dari SMK Jurusan Akuntansi, SMA Jurusan IPS dan SMA jurusan IPA. Hasil uji beda dapat dilihat pada tabel 2 dibawah ini:

\begin{tabular}{|c|c|c|c|c|c|c|c|}
\hline H & Variabel & Mahasiswa & $\mathbf{n}$ & Mean & Square & sig & Hipotesis \\
\hline \multirow{3}{*}{ H1 } & \multirow{3}{*}{ Aktiva } & SMK Ak & 30 & 3,93 & \multirow{3}{*}{0,078} & \multirow{3}{*}{0,724} & \multirow{3}{*}{ Ditolak } \\
\hline & & SMA IPS & 30 & 4,00 & & & \\
\hline & & SMA IPA & 30 & 4,03 & & & \\
\hline \multirow{3}{*}{$\mathrm{H} 2$} & \multirow{3}{*}{ Kewajiban } & SMK Ak & 30 & 3,90 & \multirow{3}{*}{0,003} & \multirow{3}{*}{0,874} & \multirow{3}{*}{ Ditolak } \\
\hline & & SMA IPS & 30 & 3,93 & & & \\
\hline & & SMA IPA & 30 & 3,96 & & & \\
\hline \multirow{3}{*}{$\mathrm{H} 3$} & \multirow{3}{*}{ Modal } & SMK Ak & 30 & 3,56 & \multirow{3}{*}{0,833} & \multirow{3}{*}{0,044} & \multirow{3}{*}{ Diterima } \\
\hline & & SMA IPS & 30 & 3,73 & & & \\
\hline & & SMA IPA & 30 & 3,40 & & & \\
\hline
\end{tabular}

Pada tabel menunjukkan bahwa hasil hipotesis 1 ditolak yang artinya tidak terdapat perbedaan yang signifikan tentang pemahaman aktiva antara mahasiswa akuntansi yang berasal dari SMK Akuntansi, SMA Jurusan IPS dan SMA jurusan IPA. Pada tahapan pengujian statistik teridentifikasi bahwa mahasiswa akuntansi yang berasal dari SMK Akuntansi, SMA IPS dan SMA IPA memiliki pemahaman yang sama dalam memahami aktiva. Keadaan tersebut tidak menggambarkan bahwa mahasiswa akuntansi yang berasal dari SMK akuntansi yang memiliki dasar ilmu akuntansi yang lebih banyak dalam berprestasi yang lebih baik dalam bentuk kuis atau ujian yang baik dibandingkan dengan mahasiswa akuntansi yang berasal dari SMA IPS maupun SMA IPA. Hasil penelitian ini didukung oleh penelitian Novius ${ }^{21}$; Sar' $^{22}$ dan Ramadhani ${ }^{23}$ yang menunjukkan hasil bahwa tidak ada perbedaan dalam

\footnotetext{
${ }^{21}$ Ibid...

22 Ibid...

${ }^{23}$ Ibid...
} 
pemahaman aktiva antara mahasiswa yang berasal/berlatang belakang SMK Akuntansi, SMA IPS maupun SMA IPA

Pengujian hipotesis 2 ditolak yang artinya bahwa tidak terdapat perbedaan pemahaman tentang kewajiban sebagai elemen laporan keuangan antara mahasiswa akuntansi yang berasal dari SMK Akuntansi, SMA IPS dan SMA IPA, keadaan tersebut terjadi karena konsep pemahaman akuntansi dasar sangat rumit dan menyangkut banyak item yang harus dihafal atau pun dilakukan dalam bentuk pemahaman dan praktek, akibatnya mahasiswa baik yang berasal dari SMA IPS, SMA IPA dan SMK Akuntansi sama-sama sulit untuk memahami kewajiban sebagai instrumen penting dalam kosep akuntansi. Kurangnya latihan, pola belajar yang tidak disiplin tentu menjadi alasan utama keadaan tersebut terjadi. Hasil penelitian ini tidak konsisten dengan hasil penelitian Mawardi ${ }^{24}$ yang menunjukkan bahwa terdapat perbedaan pemahaman mahasiswa tentang kewajiban antara mahasiswa yang berasal dari SMK jurusan akuntansi, mahasiswa tamatan SMA jurusan IPS. Hasil penelitian tersebut menunjukan mahasiswa SMK jurusan Akuntansi memiliki pemahaman yang lebih baik dari mahasiswa lain yang berasal dari SMA jurusan IPS. Tetapi hasil penelitian ini didukung oleh penelitian Ramadhani ${ }^{25}$ dan Sar' ${ }^{26}$ yang juga menunjukkan hasil bahwa tidak terdapat perbedaan secara signifikan terhadap pemahaman tentang kewajiban antara mahasiswa yang berasal dari SMK Jurusan Akuntansi dan SMA Jurusan IPS.

Pengujian hipotesis 3 diterima yang artinya bahwa terdapat perbedaan pemahaman tentang konsep modal pada mahasiswa akuntansi yang berasal dari SMK Jurusan Akuntansi, SMA jurusan IPS dan SMA jurusan IPA. Hasil yang diperoleh menunjukan bahwa mahasiswa akuntansi yang berasal dari SMK akuntansi memiliki pemahaman yang lebih baik tentang modal dibandingkan mahasiswa akuntansi yang berasal dari SMA IPS maupun SMA IPA. Keadaan tersebut terjadi karena mahasiswa akuntansi yang berasal dari SMK akuntansi telah mempelajari ilmu akuntansi dasar sejak berada dibangku SMK, aktifitas tersebut dilakukan secara berulang ulang, jam belajar yang panjang dan dilakukan secara terus menerus membuat pemahaman

24 Ibid...

25 Ibid...

${ }^{26}$ Ibid... 
instrument modal sebagai salah satu variabel penting dalam mempelajari akuntansi. Situasi tersebut menciptakan keunggulan pemahaman yang lebih baik tentang modal bagi mahasiswa akuntansi yang berasal dari SMK Akuntansi dibandingkan mahasiswa akuntansi yang berasal dari SMA IPS maupun SMA IPA. Hasil penelitian ini didukung oleh hasil penelitian $\operatorname{Sar}^{\prime}{ }^{27}$ dan $\mathrm{Ali}^{28}$ yang menunjukkan bahwa mahasiswa akuntansi yang berasal dari SMK Akuntansi memiliki pemahaman lebih tentan konsep modal dibandingkan dengan mahasiswa yang berasal dari SMA IPS dan SMA IPA.

\section{KESIMPULAN}

Berdasarkan analisis dan pembahasan hasil pengujian hipotesis yang telah dilakukan dapat diajukan beberapa kesimpulan penting yaitu sebagai berikut:

1. Tidak terdapat perbedaan yang signifikan tentang pemahaman aktiva antara mahasiswa akuntansi tamatan SMK Akuntansi, SMA IPS maupun SMA IPA.

2. Tidak terdapat perbedaan yang signifikan tentang pemahaman kewajiban antara mahasiswa akuntansi tamatan SMK Akuntansi, SMA IPS maupun SMA IPA.

3. Terdapat perbedaan yang signifikan tentang pemahaman pemahaman modal antara mahasiswa akuntansi tamatan SMK Akuntansi, SMA IPS maupun SMA IPA.

\section{DAFTAR PUSTAKA}

Ali, Adrizul, Dandes Rifa dan Daniati Putri. 2014. Analisis Tingkat Pemahaman Mahasiswa Terhadap Dasar-Dasar Akuntansi Berdasarkan Asal Sekolah dan Jurusan. Jurusan Akuntansi, Fakultas Ekonomi, Universitas Bung Hatta

Ghozali, Imam (2005), Analisis Multivariat dengan Program SPSS. Badan Penerbit Universitas Diponegoro, Semarang.

Indriantoro, Nur, dan Bambang Supomo, 2002. Metodelogi Penelitian Bisnis Untuk Akuntansi Dan Manajemen. Edisi-1,. Yogyakarta, BPFE.

27 Ibid...

${ }^{28}$ Ibid... 
Mawardi Cholid M. 2010. Tingkat Pemahaman Mahasiswa Akuntansi Terhadap Konsep Dasar Akuntansi di Perguruan Tinggi Negeri di Kota Malang. Jurnal Akuntansi Nomor 5 Volume 2. Universitas Brawijaya, Malang.

Munawir, S, 2004. Analisa Laporan Keuangan. Penerbit Liberty, Yogyakarta.

Novious Andri. 2010. Analisis Pemahaman Mahasiswa Akuntansi Dalam Menghadapi Mata Kuliah Dasar Dasar Akuntansi (Studi Pada Mahasiswa Akuntansi S1 Universitas Islam Negeri Sultan Syarif Kasim Riau). Fokus Ekonomi Volume 5 Nomor 2 Desember 2010.

Ramadhani, E. Wulan. 2017. Analisis Tingkat Pemahaman Mahasiswa Akuntansi terhadap Konsep Dasar Akuntansi. FEB Universitas Muhamadiyah Surakarta.

Santoso, Singgih, 2004. Mengolah Data Statistik Secara Profesional Versi 10. Penerbit Elex Media Komputindo, Jakarta

Sar'I., M., Irsadsyah, M., Djamil Nasrullah .2010. Analisis Tingkat Pemahaman Mahasiswa Akuntansi terhadap Konsep Dasar Akuntansi (Studi Empiris pada Mahasiswa Akuntansi S1 Uin Suska Riau yang Berasal dari Latar Belakang Sekolah Menengah yang Berbeda). Makalah: Universitas Islam Negeri Sultan Syarif Kasim Riau. 